\title{
真菌の成長による揮発性有機化合物の発生挙動と加湿器からの発生調査 EMISSION MECHANISMS OF VOC WITH GROWTH PROCESS OF FUNGUS AND EMISSION FROM HUMIDIFIER ELEMENT
}

\author{
鍵直 樹*1, 柳宇*2 \\ Naoki KAGI and U YANAGI
}

\begin{abstract}
Microorganisms produce volatile organic compounds (microbial volatile organic compounds: MVOCs). This study aimed to measure volatile organic compounds emitted from fungi by the small chamber method. Furthermore, to investigate the emission compounds from HVAC systems in a building that had odor problems in summer season, the biological contaminants on the humidifier were identified.

As a result, MVOCs such as 3-methyl-1-butanol, 1-octen-3-ol were emitted from fungi in 2 weeks. From the chamber test for the humidifier element and fungi on agars, fusarium sp. was detected on the elements and MVOC from Fusarium sp. could be identified as dimethyl disulfide.
\end{abstract}

Keywords : Microbial volatile organic compounds (MVOC), Fungi, Small chamber test 微生物由来揮発性有機化合物, 真菌, 小形チャンバー法

\section{1. はじめに}

主な室内空気污染物質として真菌などの浮遊微生物が挙げられる が, 微生物自体の健康影響だけではなく, 微生物から発生する揮発 性有機化合物（Microbial Volatile Organic Compounds, MVOC）による 目や喉一の刺激作用など健康影響が懸念される ${ }^{1)}$ 。MVOC と健康影 響については, Kim ら ${ }^{2}$ がスウェーデンの小学校児童を対象に, 健 康状態のアンケート調查とMVOC 濃度などについて調查を行った。 結果として室内の MVOC 濃度が高いとき, 夜間の息切れやぜんそ くが多く見られ，MVOC が子どものぜんそく症状の危険因子となる 可能性について指摘した。Wälinder ら ${ }^{3)}$ は, スウェーデンの 20 歳〜 54 歳の男女を対象に, 清浄空気と MVOC の一つである 3-Methylfuran をそれぞれ曝露する実験を行った。その結果, 3-Methyl-furan を 曝露後, 目の表面を覆う涙液層が不安定になっていたこと, 努力肺 活量の減少が見られたことから, 目, 気道への影響を示唆した。Araki ら ${ }^{4)}$ は, 住宅の MVOC 濃度とアンケートにより居住者の症状を評価 し, 1-Octen-3-ol の濃度と鼻や目, のどの粘膜の炎症との関係がある ことから, 粘液症状との関連を示唆した。以上のように, MVOC 単 体の健康一の影響は, 化学物質の一つであることから, ある程度の 濃度になれば, 通常の化学物質と同様に問題となる可能性があるも のの, MVOC の直接的な影響については不明な点が多い。

MVOC の発生については, 培地に生育させた真菌から発生する MVOC の測定 ${ }^{5,6)}$ を行っているものを始め, 真菌の成長と生育場所
の関係 ${ }^{7)}$, 環境中の温湿度の違いによる発生特性 ${ }^{8)}$ などが報告され ている。しかしながら, 真菌の成長に伴う MVOC の発生物質, 発生 量について, 生育環境による, 例えば微生物の栄養源すなわち培地 による発生物質の違い, 真菌の共存状態における発生形態などにつ いて検討したものは少ない。

そこで本研究では, 生育環境による真菌の成長過程と MVOC の 発生量との関係を明らかにすることを目的とし，真菌を生育させた 培地を小形チャンバーに設置し, 真菌から発生する MVOC の測定 を行った。ここでは, 真菌の違い及び栄養源となる培地の種類によ る発生物質の違い, 培地に単一種を培養した場合と複数種を混合し て培養した場合による違い, 生育過程による MVOC の発生特性に ついて検討することとした。

また空調機を有する建築物においては，空調機の適正な衛生管理 を行わなければ, 室内空気污染物質の発生源となり, 室内空気質の 悪化につながることが懸念される9)。そこで, 空調機の臭気の問題 のあった気化式加湿器エレメント表面における微生物の付着状況, 更に対象加湿器エレメントから発生する成分の分析を小形チャンバ 一法により行った。また，真菌の成長に伴う MVOC の発生特性を検 討した手法を用いて, エレメント表面に存在した微生物から発生す る MVOC の分析を行い, 臭気の発生源が加湿器エレメントに増殖 した真菌に起因するものであったかの検討を行った。
*1 東京工業大学 准教授 $\cdot$ 博士 (工学)

*2 工学院大学 教授・博士 (工学)
Assoc. Prof., Tokyo Institute of Technology, Dr.Eng.

Prof., Kogakuin University, Dr.Eng. 


\section{2. 真菌から発生する MVOC の発生量試験}

\section{1 試験方法}

\subsection{1 対象とする真菌及び栄養源}

本研究では, 培地上で生育する真菌からの MVOC を検出するた めに, 室内に存在する真菌の中から, Cladosporium cladosporioides (NBRC6348), Penicillium pinophilum (NBRC 6345), Aspergillus niger （NBRC 6341）を対象とした。栄養源となる培地としてポテトデキ ストローズ寒天培地 (PDA 培地) 及びジクロラン-グリセロール寒天 培地（DG18 培地）を用意した ${ }^{10)}$ 。なお DG18 には，成長を抑制し てコロニーを計数しやすくするためにグリセロールが用いられるが, 本研究では添加していない。これらの培地は真菌の測定によく用い られるが，得意とする真菌や生育速度などに多少違いがある ${ }^{7)}$

それぞれの真菌胞子を $10^{4} \mathrm{cell} / \mathrm{mL}$ 程度に調整し，3 枚の培地にス パイラルプレーター（IUL 製，Eddy Jet）によりシャーレ一面に 50 $\mu \mathrm{L}$ 塗沫した。また，混合試料については，上記の試料を $1 / 3$ として 混合したものを同様に培地に塗沫した。

\subsubsection{MVOC の発生量測定方法}

MVOC の発生量の測定には幾つかの方法が試みられている。培地 上及び建材上で生育させた真菌について, 20〜 $500 \mathrm{~mL}$ 程度のバイア ル及びガラスフラスコなどに入れ, SPME (Solid Phase Microextraction)で気相部分の分析を行っている ${ }^{11)}$ が, 発生量の定量

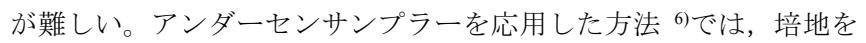
各段に設置し，発生物質を濃縮することが可能であるものの，表面 気流が速いために培地上の真菌の飛散などの影響が考えられる。気 流制御型小形チャンバーを用いた方法 ${ }^{12)}$ では, 建材上の真菌から適 切な気流状態で MVOC の発生量を測定することが可能であるが, 平面部材などが対象となり，培地を使用した試験には向かない。そ こで, 本研究では JIS A 1901 で規定している 20 L 小形ステンレスチ ヤンバーを用いて行うこととした。培地の設置量が少なくなり, 微 量な発生量に対しては不利ではあるが, 真菌への気流の影響が少な いこと, 温湿度制御が比較的簡便なこと, 一般環境に近いこと, 培 地や建材などからの MVOC の発生量測定も可能であることなどが 有利な点として挙げられる。

本研究では, Fig. 1 に示すような小形チャンバー内に上記の試験 体シャーレを 3 枚ずつ設置した。また, チャンバー内の測定条件は Table 1 に示すように，湿度を 70〜90\%に保ち，温度を $25^{\circ} \mathrm{C}$ とる ことで，真菌の生育に適した温湿度環境とした。MVOC の測定は， 培養 $1,2,3,4,7,11,14$ 日後を基本として, 一部のサンプルでは追加 した日程で行った。捕集には，Tenax 捕集剤と DNPH カートリッジ を用いて, Tenax は 60 分間で $10 \mathrm{~L}, \mathrm{DNPH}$ では 90 分で $15 \mathrm{~L}$ を捕集 し, Table 2 に示す条件で加熱脱着装置(TDS)を有する GC/MS 及び HPLC を用いて定性・定量を行った。なお, ブランクとして同条件
における小形チャンバー内及び真菌の塗抹のない培地シャーレを設 置した空気には, MVOCに関係する物質が検出していないことを確 認した。

\subsection{3 真菌観察方法}

真菌の生育状態については, 上記の捕集後, チャンバーからシャ ーレを一旦取り出し, デジタルカメラにより外観の記録を行った。 その後, シャーレをチャンバー内に戻し, 引き続き次の捕集に備え た。

\section{2 真菌の観察結果及び実験結果 \\ 2.2 .1 真菌の観察結果}

Fig. 2 に各真菌・各培地の成長の様子について示す。いずれも 2 日 目に菌系の成長が認められ，その後 3 又は 4 日目以降に胞子の色づ きが確認された。P.pinophilum については，7 日目以降に更に青く色 づいた。また, 培地による生育速度の違いは C.cladosporioides 及び P.pinophilum についてはコロニーの密度により若干異なるもののほ ぼ同様で, A.niger についてはDG18の方が遅い傾向となった。混合 試料については, PDA 培地では A.niger の成長が培地表面のほぼ全 面に, DG18 培地では P.pinophilum が $3 / 4$ 程度で支配的であった。

\subsubsection{MVOC の種類と発生量変化}

Table 3 に各真菌・各培地から検出された MVOC の成分について 示す。各真菌, 各培地共に Acetaldehyde, Acetone 及び 3-Methyl-1butanol が検出された。条件によっては検出下限以下であった物質が あるが, PDA でのみ検出された物質は, C.cladosporioides の 3-Methyl-

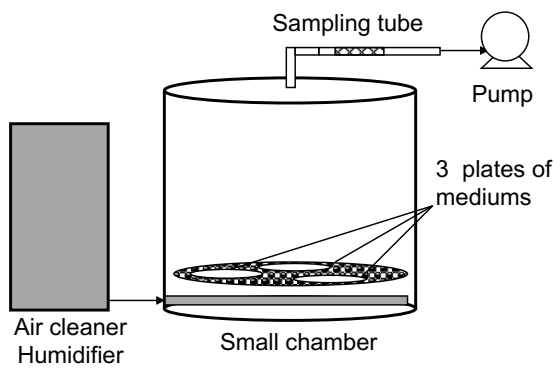

Fig. 1 Small chamber method in this study

Table 1 Conditions of the small chamber method

\begin{tabular}{|c|c|}
\hline Chamber volume & $20 \mathrm{~L}$ \\
\hline Temperature & $25^{\circ} \mathrm{C}$ \\
\hline Humidity & $70 \sim 90 \% \mathrm{Rh}$ \\
\hline Air volume & $0.167 \mathrm{~L} / \mathrm{min} .(0.5-/ \mathrm{h})$ \\
\hline Measurement period & For 14 days \\
\hline Sampling volume & DNPH:15 L \\
\hline Sampling time & Tenax:60 min. $\quad$ DNPH:90 min. \\
\hline
\end{tabular}

Table 2 Analysis conditions for GC/MS, TDS and HPLC

\begin{tabular}{|c|c|c|c|c|c|}
\hline GC/MS & HP 6890 & TDS & Gestel TDSA & HPLC & HP 1100 \\
\hline \multirow[t]{2}{*}{ Column } & InertCap 5MS/Sil & Desorp. temp. & $270{ }^{\circ} \mathrm{C}$ & Column & 20RBAX Eclips XDB-C18(4.5x250mm) \\
\hline & $0.25 \mathrm{~mm} \varphi \times 60 \mathrm{~m} \times 0.25 \mu \mathrm{m}$ & Desorp. time & $10 \min$. & Injection & $10 \mu \mathrm{L}$ \\
\hline Oven temp. & $40^{\circ} \mathrm{C}(5 \mathrm{~min})-.\left(10^{\circ} \mathrm{C} / \mathrm{min}.\right)-250^{\circ} \mathrm{C}(10 \mathrm{~min})$. & Cryo temp. & $-50^{\circ} \mathrm{C}$ & Detector & UV $365 \mathrm{~nm}$ \\
\hline Carrier gas & $\mathrm{He}$ & Trap temp. & $270^{\circ} \mathrm{C}$ & Flow & $1 \mathrm{~mL} / \mathrm{min}$. \\
\hline Gas flow & $1.0 \mathrm{~mL} / \mathrm{min}$ & Trans. temp. & $280^{\circ} \mathrm{C}$ & Column temp. & $35^{\circ} \mathrm{C}$ \\
\hline Anal. mode & SCAN (30-450) & & & Mobile phase & $\mathrm{CH}_{3} \mathrm{CN} / \mathrm{H}_{2} \mathrm{O}=65 / 35$ \\
\hline
\end{tabular}




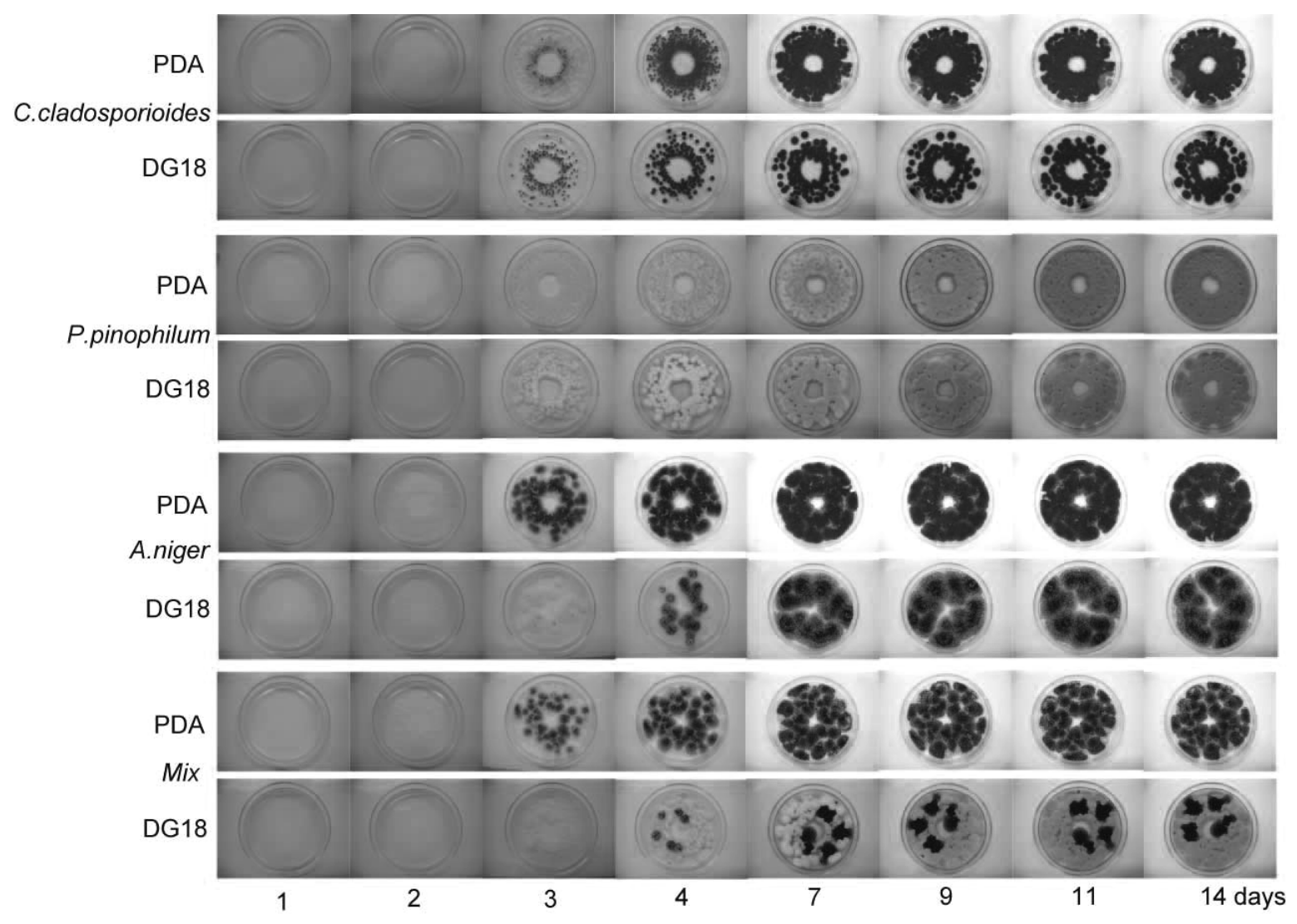

Fig. 2 Observations of each fungal growth of C. cladosorioides, P. pinophilum, A. niger and mix sample on PDA and DG18 agar

3-buten-1-ol, P.pinophilum の 3-Methyl-1-buten-1-ol, 2-Octanone, 2Octanol, A.niger の 3-Methyl-3-buten-1-ol 及び 2-Methyl-furan となり, DG18 培地では P.pinophilum の 3-Octanol, A.niger の 1-Octen-3-ol, 3Octanone，3-Octanol となった。

Fig. 3 に各試料の MVOC 発生量と経過日数の関係を示す。なお, ここでの発生量は, 試験体シャーレ 3 枚の蓋を開けて静置した全体 の発生量とした。傾向として, 菌糸のみが確認できる 2 日目でも Acetaldehyde 又は Acetone が検出され, 胞子が色づいて見える 3, 4 日目に VOCs のピークを持ち, 成長が停止する 7 日目以降は低い発 生量の傾向となった。培地別には, C.cladosporioides を除き, 発生量 の值は異なるものの同様の傾向となっている。C.cladosporioides で は, 3-Methyl-1-butanol が PDA で 3 日目に DG18 で 4 日目に, P.pinophilum では，色が変化する 7 日目以降に 1-Octen-3-ol の他，2Octanone, 3-Octanol なども検出された。また, A.niger は, 2-Methyl1-propanol 及び 3-Methyl-1-butanol が 3 日目にピークを持った。混合 試料については, PDA では A.niger の成長が支配的で, この単体で の発生量も少なかったことから MVOC の発生量が少なくなったも のと考えられる。一方 DG18 培地では, P.pinophilum の生育が支配的 であったことから, P.pinophilum から発生した Acetone, Acetaldehyde 及び 3-Methyl-1-butanol の発生量が同様に大きく, 色づく 7 日目以降 に検出された 1-Octen-3-ol が混合試料でも遅れて検出された。

2 日目にはどの真菌も胞子が色づいておらず，目には見え難い菌 糸の成長段階でも MVOC が発生し, 発生量のピークは各真菌コロ ニーが色づく段階と一致し, その後減衰する傾向であった。その後
Table 3 MVOCs emitted from each sample

\begin{tabular}{|c|c|c|c|c|c|c|c|c|}
\hline & \multicolumn{2}{|c|}{\begin{tabular}{|c|} 
C. \\
cladosporioides
\end{tabular}} & \multicolumn{2}{|c|}{ P.pinophilum } & \multicolumn{2}{|c|}{ A.niger } & \multicolumn{2}{|c|}{ Mix } \\
\hline & PDA & DG18 & PDA & DG18 & PDA & DG18 & PDA & DG18 \\
\hline Acetaldehyde & 0 & 0 & 0 & 0 & 0 & 0 & $\mathrm{O}$ & 0 \\
\hline $\begin{array}{l}\text { Acetone } \\
\text { 2-Methyl-furan }\end{array}$ & 0 & 0 & 0 & 0 & $\begin{array}{l}0 \\
0\end{array}$ & O & 0 & 0 \\
\hline $\begin{array}{l}\text { 2-Methyl-1-propanol } \\
\text { 3-Methyl-3-buten-1-ol }\end{array}$ & 0 & & O & O & $\begin{array}{l}0 \\
0\end{array}$ & O & O & O \\
\hline $\begin{array}{l}\text { 3-Methyl-1-butanol } \\
\text { 3-Methyl-2-buten-1-ol }\end{array}$ & O & O & $\begin{array}{l}\mathrm{O} \\
\mathrm{O}\end{array}$ & 0 & 0 & 0 & O & O \\
\hline $\begin{array}{l}\text { 1-Octen-3-ol } \\
\text { 2-Octanone }\end{array}$ & O & 0 & $\begin{array}{l}\circ \\
\mathrm{O}\end{array}$ & O & & 0 & O & 0 \\
\hline 3-Octanone & & & & 0 & & $\circ$ & & 0 \\
\hline $\begin{array}{l}\text { 3-Octanol } \\
\text { 2-Octanol }\end{array}$ & & & $\begin{array}{l}0 \\
0\end{array}$ & 0 & & 0 & & 0 \\
\hline
\end{tabular}

成長が止まると, 発生が低減されることが明らかとなった。培地上 での真菌の成長については, 培地一の真菌胞子の接種の方法により 異なる。例えば培地中央に 1 点接種すると, 培地表面に真菌が周囲 に広がりながら成長を続ける。今回の条件では，培地上に均一に接 種しているため, 各コロニーが同時に成長し，培地表面に拡大でき る場所がなくなると成長が止まることから, MVOC の発生にピーク が存在し，その後減衰する傾向となったものと考えられる。以上よ り, 真菌の成長の度合いに応じて, MVOC の種類, 発生量が異なる ことが明らかとなった。

\section{3. 気化式加湿器ろ材からの MVOC の発生 3.1 対象建物設備の概要と污染原因}

対象とした建物については, 夏期に居住者から空調吹き出し口か らの臭気に関する苦情が発生し, 空調機内部の気化式加湿器エレメ 

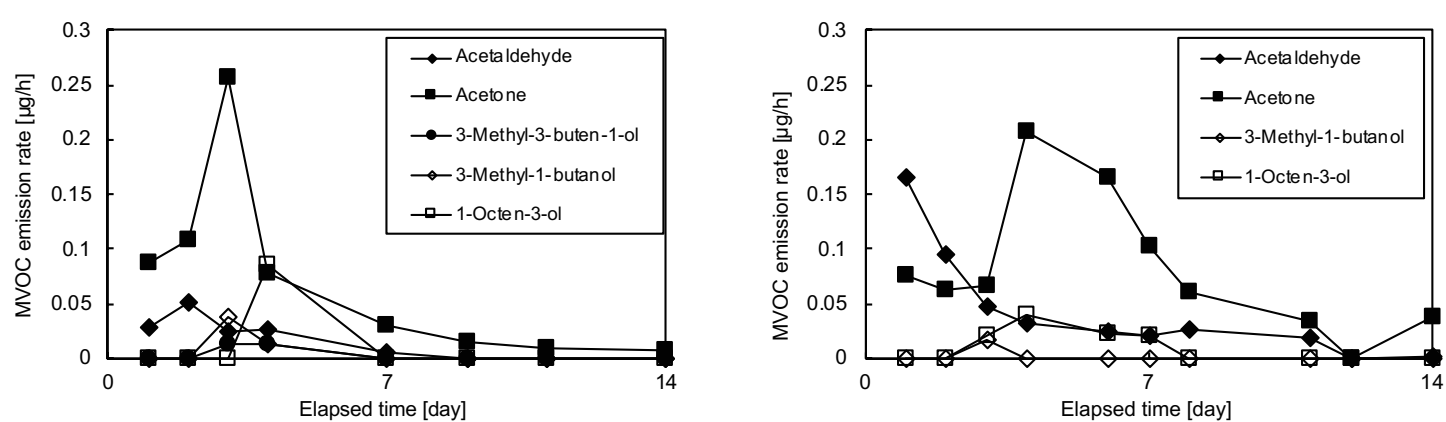

a) C.cladosporioides
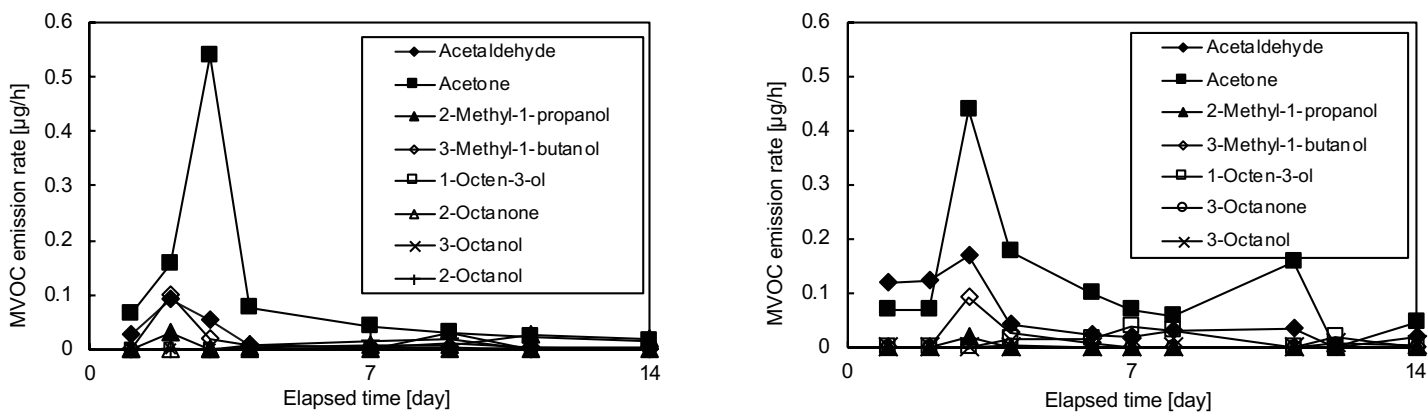

b) P.pinophilum
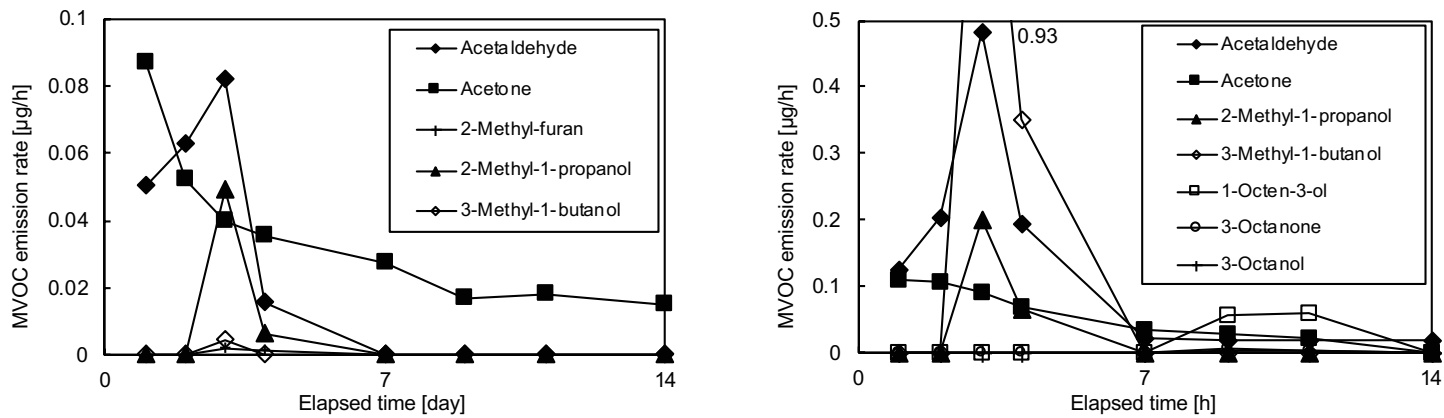

c) A.niger
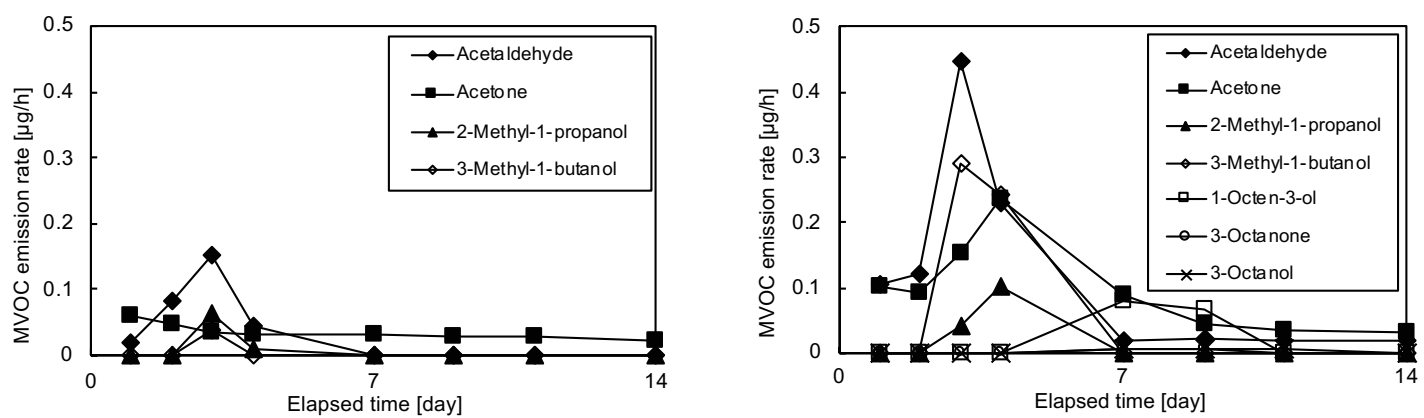

d) Mix

Fig. 3 MVOC emission changes for each fungus (Left: PDA, Right: DG18)

ントの污染が原因と推定されたことから，このエレメント表面にお

ける微生物の付着及び MVOC の発生について検討を行った。この 建物の空調方式は各階方式で, 対象とした空調機は外気を処理する 外調機であった。

通常空調機からの臬気の問題については, 朝や月曜日の運転開始 直後に, 空調機内部に蓄積した污染物質が一気に放出されることに よる要因が大きい。空調機内部の温湿度環境は微生物の生育に好ま
しく ${ }^{13)}$, 特に夏期の冷却コイルや冬期の加湿器エレメント表面など, 機器の動作中においては適切な維持管理が污染の予防に必要となる。 また, 気化式加湿器については, 加湿中において加湿水中や加湿器 エレメント表面に微生物が繁殖し, 室内微生物污染の原因となるこ とが考えられている ${ }^{14,15)}$ 。よって, 夏期の加湿器が動作していない 際には, 加湿器エレメント表面は比較的乾燥しており, 微生物が繁 殖する危険性は少ないものと考えていた。 
しかし今回対象とした建物の空調内部においては，夏期の冷房運 転期間において, 気化式加湿器エレメント表面での濡れを確認し, この部分において微生物が繁殖することにより臭気の発生源となっ ていることが疑われた。冷房運転により加湿器エレメントが濡れた 原因として，空調の運転によってこの空調機内部の冷却コイル上の 凝縮水がエレメントに飛散したこと, 冷却コイルと加湿器ケーシン グとの熱橋によってケーシングが冷却され, その表面での結露水が エレメント表面に到達したことなどが考えられる。更に，エレメン トが濡れていた空調機は，外調機であり夏期には高湿度の空気を取 り込んでいること, 空調機の発停などの運転条件など, 様々な因子 が重なったことによるものと考えられる。

そこで, この加湿器エレメントの表面付着菌及び VOC の発生の 調査を行うこととした。

\section{2 測定方法の概要}

\section{2 .1 表面付着菌の測定方法}

エレメント表面の付着微生物の調査には，蒸留水を $10 \mathrm{~mL}$ 入れ ストマック袋に, 対象建物にあった加湿器エレメントを $5 \times 6 \mathrm{~cm}$ に 切り出したものを 2 枚入れ, 表面の付着成分を抽出した。抽出した 溶液は，スパイラルプレーターを用い，細菌の分析のためソイビー ン-カゼインダイジェスト培地 (SCD 培地), 真菌のためPDA 培地及

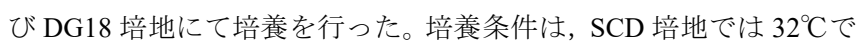
2 日間, $\mathrm{PDA} 及 ひ ゙ \mathrm{DG} 18$ 培地では $25^{\circ} \mathrm{C}$ で 5 日間とした。培養後, コ ロニー数の計数を行い, 加湿器エレメント表面積あたりの付着数を 算出した。

\subsection{2 エレメント及び付着菌からの VOC の測定方法}

加湿器エレメントからの VOC 発生については，実際に使用して いた加湿器のエレメントを $150 \mathrm{~cm}$ 角に切り出し, この表面全体に 蒸留水を霧吹きにて流れ出ない程度に噴霧することで常時湿らせ, 前章で示した小形チャンバーによる MVOC の測定と同様に，温度 $25^{\circ} \mathrm{C}$, 相対湿度 70〜90\%の環境に設置した。そしてこの試験体を設 置してから，1,3, 7, 14 日目に発生物質のサンプリングを行い, VOC の測定を行った。同様に污染されていない新品のエレメントについ ても，同様の条件で発生するVOCの測定を行った。なお，VOCの 捕集・分析条件は，前章と同様に行った。

一方，エレメントに付着した真菌からの MVOC 発生の確認につ いては, 加湿器エレメント表面より分離した真菌を 2.1.2 で行った 手法と同様にPDA 培地に塗布した。なお, この時の真菌の胞子数は 確認できていない。培養 2, 4, 7, 14 日後に上述と同様に小形チャン バーを用いて, 発生した MVOC の捕集を行った。VOC の捕集, 分 析条件についても, 前章と同様である。

\section{3 調査結果}

\subsection{1 加湿器エレメント表面付着菌}

Table 4 に対象とした加湿器エレメント表面付着菌の測定結果を 示す。SCD 培地による細菌数に比べ, PDA, DG18 培地による真菌数 の方が格段に多くなった。また, 真菌の中ではFusarium sp.が主に検 出された。PDA 及び DG18 培地は共に同様の傾向であったことから も, この加湿器エレメントは, Fusarium sp.により污染されており, これから発生した成分が室内の臭気の原因になった可能性がある。
Table 4 Microorganisms on element surface of humidifier

$\left[\mathrm{cfu} / \mathrm{cm}^{2}\right]$

\begin{tabular}{ll|lc|c}
\hline \multicolumn{1}{c|}{ SCD } & \multicolumn{1}{|c|}{ PDA } & DG18 \\
\hline Gram-positive coccus & 5 & Fusarium sp. & 748 & 648 \\
Endosore & 5 & Cladosporium sp. & 5 & 1 \\
& & Alternaria sp. & 5 & 12 \\
\hline
\end{tabular}

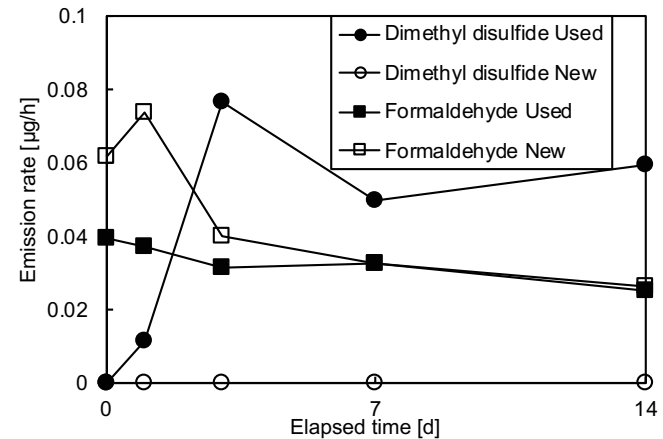

Fig. 4 VOC emission changes from humidifier elements

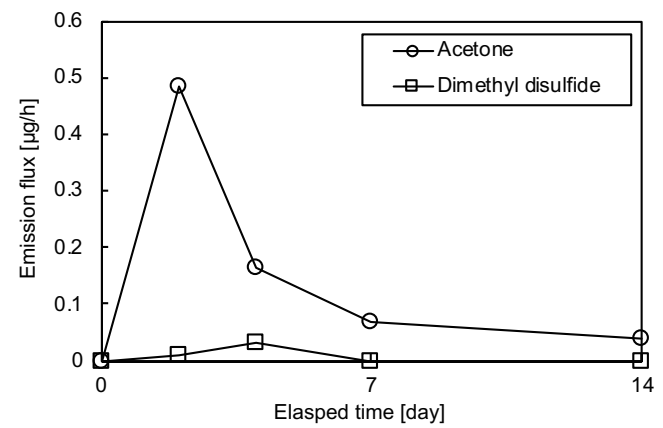

Fig. 5 MVOC emission from Fusarium sp. on agar medium

\subsection{2 加湿器エレメントから発生する VOC}

加湿器エレメントの新品及び対象とした空調機に使用されていた サンプルから発生した VOCについては, 両者に大きな違いはなく， シール材などで使用されている低分子シロキサン類(LMCS)などが 検出された。主に加湿器エレメントを構成する材料から発生した成 分が検出されたことによるものと考えられる。使用したエレメント のみから発生した物質として，微量ではあるが Dimethyl disulfide が 検出された。既往の研究 ${ }^{16)}$ において, Fusarium oxysporum から Dimethyl disulfide の生成が確認されている。なお, Dimethyl disulfide については環境省悪臭防止法において特定悪臭物質に特定され，「腐 ったキャベツのような臭い」と表現されている。実際の使用したエ レメントについては，上述の臭いとは確認できなかったものの悪臭 を感じた。

Fig. 4 に，それぞれのエレメントから発生した Formaldehyde と Dimethyl disulfide の発生量の経時変化を示す。Formaldehyde は材料 自体から発生しているものと考えられ，時間と共に徐々に減少して いる傾向となっており，通常の材料から発生する VOC の低減と同 様の発生形態となった。一方, Dimethyl disulfide については, 新品 エレメントでは検出されなかったのに対し，污染されたエレメント 
では, 1 日目から検出され, 3 日目で最大となり, その後も検出され 続けた。新品エレメント表面では Fusarium sp.が付着していないた め, Dimethyl disulfide が検出されなかったのに対し, 表面に Fusarium sp.が付着しているエレメントからは Dimethyl disulfide が検出された こと, 更に時間の経過と共に増加し, 発生が続くことから, 使用し た加湿器エレメント表面に付着していた Fusarium sp.が Dimethyl disulfide の発生源であることが示唆された。

\subsubsection{Fusarium sp.から発生する MVOC}

小形チャンバーを用いて Fusarium sp.から発生した MVOC を確認 したところ, Acetone 及び使用済みのエレメントと同様に微量であ るが Dimethyl disulfide が検出された。Fig. 5 に Fusarium sp.から発生 した Acetone 及び Dimethyl disulfide の発生速度の経時変化を示す。 PDA 培地上の Fusarium sp.の成長は, 培養後 2 日目程度で菌系が生 成し，5 日目には胞子が形成され, それ以降成長が停止している状 態であった。発生量の経時変化としては, Acetone が 2 日目の早い 段階でピークとなり，その後減少した。一方 Dimethyl disulfide につ いては，5 日目にピークとなり, その後減少する傾向となり, 両者 の発生量のピークには違いがあった。前章においても, 菌系と胞子 の成長のタイミングと検出された MVOC によって, 同様に異なる 発生量のピークを持つ傾向となっていた。よって, Fusarium sp.の成 長により発生する MVOC として Dimethyl disulfide があり, 污染さ れたエレメントからも同様に検出されたことから, エレメントに付 着していた Fusarium sp.から Dimethyl disulfide が発生したものと考 えられる。

今回, 建物内における空気質の測定を行っていないため, 室内に おける臭気の原因物質でMVOCに関係する物質が Dimethyl disulfide であったかは明確ではないが，エレメント表面に付着した微生物由 来のMVOC が臭気に関連していた可能性が高いと考えられる。

加湿を行っていない夏期において, 結露水により加湿器エレメン トが濡れたことが，今回の臭気の発生の原因となっていたものと考 えられることから, 濡れを排除することが夏期の加湿器污染による 室内空気質の維持に重要となる。全ての空調機で問題となっている とは限らないが, 今回は熱交換器からの結露水の飛散, 熱橋による 加湿器ケーシングの結露などが考えられた。また, 空調機の運転状 況によっても, 結露の状況が変わるものと考えられる。結露水の飛 散防止やケーシングの断熱などの対策が考えられるが, 夏期には使 用しない加湿器エレメントを一時期取り外すことでも, 污染のリス クを減らすことになり，有効な方法であると考えられる。

\section{4. まとめ}

真菌からの MVOC 発生量について, 真菌の成長との関連を考慮 に入れ，小形チャンバーを用いてその関係について把握した。さら に, 空調機から発生した臭気の原因究明として, 加湿器エレメント 表面における微生物の付着状況, 加湿器エレメントから発生する成 分の分析及びエレメント表面に存在した微生物の MVOC の分析を 行い，以下のような知見を得た。

1)培地の違いによる MVOC の発生について, PDA でのみ測定され た物質は, P.pinophilum の 3-Methyl-1-buten-1-ol, 2-Octanone, 2-Octanol, A.niger の 3-Methyl-3-buten-1-ol 及び 2-Methyl-furan となり, DG18 培 地では P.pinophilum の 3-Octanol, A.niger の 1-Octen-3-ol, 3-Octanone,
3-Octanol が検出され，培地により MVOC 発生が若干異なることが 示された。

2)菌糸及び胞子の成長段階で, Acetaldehyde 及び 3-Methyl-1-butanol などの MVOC が多く検出された。また, 後半に 1-Octen-3-ol，2Octanone, 3-Octanol などの物質が検出された。さらに, 各真菌のコ ロニーが色づく段階と MVOC の発生量のピークが一致し, 成長が 止まると MVOCの発生もなくなる傾向となった。

3)対象とした外調機の加湿器エレメント表面付着菌の測定では, Fusarium sp.が多く検出された。加湿器エレメントからの VOC の測 定の結果, Dimethyl disulfide が検出され, また時間の経過と共に増 加する傾向があったことから, 加湿器エレメント表面に付着してい た Fusarium sp.が Dimethyl disulfide の発生源であることが考えられ た。

4)培地に培養した Fusarium sp.から発生する MVOCを測定した結果, 加湿器エレメントから発生した Dimethyl disulfide が検出された。更 に菌系と胞子の成長のタイミングと, Fusarium sp.から発生した Dimethyl disulfide の発生の傾向からも Fusarium sp. 由来の MVOC で あることが明らかになった。よって, 今回の加湿器エレメント表面 においては, Fusarium sp.により污染され，これによる MVOC の発 生が臭気の原因であることを示唆した。

\section{謝辞}

本研究は厚生労働科学研究費補助金 (地域健康危機管理研究事業) により行われた。記してここに感謝の意を表す。

\section{参考文献}

1) Nilsson, A., Kihlström, E., Lagesson, V., Wessén, B., Szponar, B., Larsson, L. and Tagesson, C.: Microorganisms and volatile organic compounds in airborne dust from damp residences, Indoor Air, Vol. 14, No. 2, pp. 74-82, 2004.4

2) Kim, J.L., Elfman, L. Mi, Y., Wieslander, G., Smedje, G. and Norbäck, D.: Indoor molds, bacteria, microbial volatile organic compounds and plasticizers in schools - associations with asthma and respiratory symptoms in pupils, Indoor Air, Vol. 17, No. 2, pp. 153-163, 2007.4

3) Wålinder, R., Ernstgård, L., Johanson, G. Norbäck, D., Venge, P. and Wieslander, G.: Acute effects of a fungal volatile compound, Environ Health Perspectives, Vol. 113, pp. 1775-1778, 2005.12

4) Araki, A., Kawai, T., Eitaki, Y., Kanazawa, A., Morimoto, K. Nakayama, K., Shibata, E., Tanaka, M., Takigawa, T., Yoshimura, T., Chikara, H., Saijo, Y. and Kishi, R. : Relationship between selected indoor volatile organic compounds, socalled microbial VOC, and the prevalence of mucous membrane symptoms in single family homes, Science of the Total Environment, Vol. 408, pp. 2208-2215, 2010.4

5) Park, J.S., Kawajiri, D., Ikeda, K. and Fujii, S.: Study on volatile organic compounds emissions from fungi in HVAC system, Journal of Architecture, Planning and Environmental Engineering (Transactions of AIJ), Vol. 67, No. 552, pp. 43-48, 2002.2 (in Japanese)

朴俊錫, 川尻第貴, 池田耕一, 藤井修二 : 真菌由来揮発性有機化合物による 空気調和機污染に関する研究, 日本建築学会計画系論文集, 第 67 巻, 第 552 号, pp.43-48, 2002.2

6) Park, J.S. and Ikeda, K.: Indoor air pollution by microbial volatile organic compounds in indoor environment Part 2 Study on effect of formaldehyde emission on fungal growth on plywood materials, Journal of Environmental Engineering (Transactions of AIJ), Vol. 69, No. 577, pp. 27-31, 2004.3 (in Japanese) 朴俊錫，池田耕一：居住空間における真菌由来揮発性有機化合物による室 内空気污染に関する研究 その 2 合板におけるホルムアルデヒド放散量 による真菌成長への影響, 日本建築学会環境系論文集, 第 69 巻, 第 577 号, pp. 27-31, 2004.3 
7) Fieldler, K., Schütz, E. and Geh, S.: Detection of microbial volatile organic compounds (MVOCs) produced by moulds on various materials, International Journal of Hygiene and Environmental Health, Vol. 204, pp. 111-121, 2001

8) Polizzi, V., Adams, A., Saeger, S. D., Peteghem C. V., Moretti, A. and Kimpe, N.: Influence of various growth parameters on fungal growth and volatile metabolite production by indoor molds, Science of the Total Environment, Vol. 414, pp. 277286, 2012.1

9) Liu, Z., Ma, S., Cao, G., Meng, C., He, B.: Distribution characteristics, growth, reproduction and transmission modes and control strategies for microbial contamination in HVAC systems: A literature review, Energy \& Buildings, 177, pp. 77-95, 2018.

10) Yanagi U: Comparison between PDA and DG1 8 medium for measurement of fungi, Clean Technology, Vol. 17, No. 11, pp. 30-33, 2007.11

柳宇: カビ測定における PDA と DG18 培地の比較, クリーンテクノロジー, Vol. 17, No. 11, pp. 30-33, 2007.11

11) Wady L., Bunte, A., Pehrson, C. and Larsson, L.: Use of gas chromatographymass spectrometry/solid phase microextraction for the identification of MVOCs from moldy building materials, Journal of Microbiological Methods, Vol. 52, No. 3, pp. 325-332, 2003

12) Hirose, M., Murakami, S., Kato, S., Ooka, R., Seo, J.H. and Abe, K.: Measurement of MVOCs (microbial volatile organic compounds) emissions from fungi on building materials, Summaries of Technical Papers of Annual Meeting, Architectural Institute of Japan, Environmental Engineering-II, D- II, pp. 895-896, 2006.7 (in Japanese)

弘瀬将光, 村上周三, 加藤信介, 大岡龍三, 徐長厚, 阿部恵子: 建材におけ る真菌起源揮発性有機化合物(MVOC)の放散量の測定, 日本建築学会大会 学術講演梗概集, D- II, pp. 895-896, 2006.7
13) Yanagi, U. and Ikeda, K.: Research on the behavior and control of microbial contamination in an air conditioning system Part 1 Growth environment and contamination on status of microbes, Journal of Environmental Engineering (Transactions of AIJ), Vol. 70, No. 593, pp. 49-53, 2005.7 (in Japanese) 柳宇, 池田耕一: 空調システムにおける微生物污染の実態と対策に関する 研究 第 1 報微生物の生育環境と污染実態, 日本建築学会環境系論文集, 第 70 巻, 第 593 号, pp. 49-56, 2005.7

14) Katsui, N., Nakata, H., Sakamoto, M., Nishikawa, F. and Kita, E.: Experimental study on the microbial contamination of evaporating-Type humidifiers, Transactions of the Society of Heating, Air-Conditioning Sanitary Engineering in Japan, Vol. 21, No. 61, pp. 37-44, 1996.4 (in Japanese)

勝井則明, 中田春男, 坂本雅子, 西川文子, 喜多英二: 気化式加湿器の微生 物污染に関する実験的研究, 空気調和・衛生工学会論文集, Vol. 21, No.61, pp. 37-44, 1996.4

15) Yanagi, U., Kagi, N. and Ikeda, K.: Research on the behavior and control of microbial contamination in an air conditioning system Part 4 Investigation for a mold smell source related to an individual air conditioning system, Journal of Environmental Engineering (Transactions of AIJ), Vol. 75, No. 654, pp. 721-726, 2010.8 (in Japanese)

柳宇, 鍵直樹, 池田耕一: 空調システムにおける微生物污染の実態と対策 に関する研究 第 4 報個別方式における「かび臭」原因究明のための調査, 日本建築学会環境系論文集, Vol. 75, No. 654,pp. 721-726, 2010.8

16) Auger, J. Arnault, I., Diwo-Allain, S., Ravier, M., Molia, F. and Pettiti, M.: Insecticidal and fungicidal potential of Allium substances as biofumigants, Agroindustia, No.3, pp. 5-8, 2004.1 


\title{
EMISSION MECHANISMS OF VOC WITH GROWTH PROCESS OF FUNGUS AND EMISSION FROM HUMIDIFIER ELEMENT
}

\author{
Naoki KAGI ${ }^{* 1}$ and $U$ YANAGI ${ }^{* 2}$ \\ *1 Assoc. Prof., Tokyo Institute of Technology, Dr.Eng. \\ ${ }^{* 2}$ Prof., Kogakuin University, Dr.Eng.
}

Fungi as a microbial contamination of indoor environments may cause a complex spectrum of health effects. Spores of fungi may cause allergies, asthma and sometimes contain mycotoxins. Microorganisms also produce many volatile organic compounds (microbial volatile organic compound (MVOC)). The toxicological aspect of MVOCs may be negligible because of low concentrations in indoor spaces, however MVOCs sometimes attribute an unpleasant smell.

This study aimed to measure volatile organic compounds emitted from fungi by the small chamber method and investigate emission patterns of MVOCs as fungal growth processes. Furthermore, to investigate the emission compounds from HVAC systems in a building that had odor problems in the room in summer season, the biological contaminants on the humidifier were identified and the small chamber tests for emissions from the humidifier element and biological contaminants were carried out.

The Cladosporium cladosporioides, Penicillium pinophilum, Aspergillus niger and mixture of these three fungi on the PDA (potato dextrose agar) medium and DG18 (dichloran glycerol) agar without glycerol were installed in the stainless small chamber $(20 \mathrm{~L})$, and the emitting volatile organic compounds were sampled with DNPH cartridge and Tenax sampler during 2 weeks. The temperature and humidity inside the chamber were kept at $25{ }^{\circ} \mathrm{C}$ and $70-90 \%$, respectively. The samples were analyzed with a high performance/pressure liquid chromatography (HPLC) and a gas chromatograph I mass spectrometer (GC/MS). The sampling of emitting MVOCs and observation of the fungal growth under a microscope were carried out at fixed intervals for 2 weeks.

Fungal threads of all samples invisibly grew until 2 days, and growth and changing color of spores to black or yellow were occurred after 3 or 4 days. P. pinophilum changed its color to blue after 7 days again. The relationships between the growth of the fungal threads and spores, and MVOC emitting rates were investigated. Fungi could not be visible but grew their thread, however invisible fungi emit MVOCs such as acetaldehyde, acetone, 2-methyl-1-propanol and etc. When the fungi grew with their spores and change their color, other MVOCs such as 3-methyl-1-butanol, 1-octen3-ol were emitted in 2 weeks. Then as stopping growing, MVOC emissions decreased.

From the chamber test for the humidifier element and fungi on agar mediums, Fusarium sp. was detected on the elements and MVOC from Fusarium sp. could be identified as dimethyl disulfide. Since dimethyl disulfide was also detected from the humidifier element by the chamber method, the source of the odor in the room could be the humidifier element surface contaminated by Fusarium sp. 